Олеся Лемішовська

Національний університет

«Львівська політехніка» ORCID ID 0000-0002-5695-0924

Ірина Яремко

Національний університет «Львівська політехніка»

ORCID ID 0000-0001-9772-6817

DOI 10.24139/2312-5993/2020.03-04/077-091

\title{
УДОСКОНАЛЕННЯ ФАХОВИХ КОМПЕТЕНТНОСТЕЙ У ПРОЦЕСІ ПІДГОТОВКИ ВИКЛАДАЧІВ ОБЛІКОВО-ЕКОНОМІЧНИХ ДИСЦИПЛІН З ВИКОРИСТАННЯМ ІННОВАЦІЙНИХ ПЕДАГОГІЧНИХ ТЕХНОЛОГІЙ
}

\begin{abstract}
Стаття присвячена теоретичному обгрунтуванню значимості і змісту інноваційних педагогічних технологій для вдосконалення профресійної компетентності майбутнього викладача професійного навчання. Наведено сучасні тенденції в розвиткові університетської освіти та проаналізовано зміст і характер пропонованих педагогічних технологій із використанням інноваційного інструментарію. Розкрито стан та проблеми використання інноваційних педагогічних технологій у вдосконаленні специфічних компетентностей викладача обліково-економічних дисциплін. На основі узагальнення тематичних досліджень $і$ практики сформульовані окремі пропозиції щодо використання інноваційного інструментарію за досліджуваним профілем підготовки спеціалістів.

Ключові слова: викладач обліково-економічних дисциплін, профресійна підготовка, освітні інновації, інноваційна освітня діяльність, компетентності, технології в освіті, педагогічні технології.
\end{abstract}

Постановка проблеми. У сучасному світі освіта й наука об'єктивно постають пріоритетними чинниками соціального, економічного та культурного розвитку будь-якої країни. Нові вимоги до компетентностей здобувачів вищої освіти зумовлюють необхідність докорінного перегляду узвичаєної технології і методики для модернізації навчального процесу за будь-яким напрямом підготовки спеціалістів. Набір фахових компетентностей 3 переважної більшості напрямів підготовки спеціалістів динамічно змінюється, а їх забезпечення вирішується шляхом упровадження інноваційних технологій. Наведене стосується визначеного авторами напряму професійної підготовки спеціалістів. У цьому контексті вкажемо, що міжнародна федерація бухгалтерів - International Federation of Accountants (IFAC) - розробляє стандарти професійної освіти. Вони гармонізовані в міжнародних масштабах і спрямовані на забезпечення дедалі зростаючих і динамічно змінюваних вимог до бухгалтерської професії. При цьому у сфері бухгалтерського навчання, як і в інших напрямах підготовки спеціалістів, «методологічний ландшафт сучасних освітніх трансформацій спрямований на 
формування інноваційної особистості», позначаються зближенням теоретичних та практичних аспектів діяльності й забезпечується на основі «процедурно-технологічних потенцій наукової теорії та модельноінформаційних здатностей практики» (Гулько, 2012, с. 471).

Магістральна спрямованість модернізації сучасної освіти лежить у координатах компетентнісного підходу, який витісняє знаннєву парадигму з дидактики. Новий зміст освітніх технологій передбачає не тільки засвоєння інформації, а більшою мірою спрямовується на вироблення аналітико-оцінних навичок, набуття здатностей приймати рішення в умовах змін професійної діяльності. Загалом можна стверджувати, що переосмислення змісту вищої освіти полягає в переході від ії традиційного «пізнавального змісту» до формування моделі «розбудови потенціалу». Успішність упровадження такої моделі дедалі частіше пов'язується з такою складовою, як поєднання фахових знань і педагогічних навичок. Тобто, по суті, йдеться про поняттєвий зміст «педагогічної технології», який, наприклад, за визначенням ЮНЕСКО розкритий як «системний метод створення, застосування й визначення всього процесу викладання i засвоєння знань з урахуванням технічних і людських ресурсів у їх взаємодії, що вирішує завдання оптимізації форм освіти».

у сучасних публікаціях аргументується, що якість навчального процесу залежить від «синергетичного набору» - «педагогічна майстерність» + «професійні знання». Тому в багатьох зарубіжних публікаціях акцентованим виступає твердження про те, що професійні знання викладачів закладів вищої освіти повинні бути підкріплені педагогічними знаннями (університетська педагогіка), обґрунтовуючи «необхідність розвитку педагогічної підготовки викладачів університетів» (Asonitou; Paisey \& Paisey, 2004). Такої самої позиції дотримуються не тільки в педагогічних колах, але й авторитетних суто фахових міжнародних журналах «Бухгалтерська освіта» (Accounting Education). Узагальнено вкажемо, що розвиток педагогічних технологій у системі бухгалтерського навчання розглядається через системну сукупність усіх задіяних фахових, інструментальних і методологічних засобів у параметрі психологопедагогічних, науково-технологічних та соціально-економічних нововведень, які можуть бути реалізованими в системі освітніх інновацій.

Розгляд існуючої проблематики на сторінках журналів 3 бухгалтерської освіти пов'язується, насамперед, із тим, що в реально складених умовах глобалізації і динаміці технологічних інновацій іншого характеру і функціональної спрямованості набуває сама бухгалтерська професія. Відповідно, іншого змісту потребує й фокус освітнього процесу, який зміщується в напрям забезпечення нових компетентностей. У загальну компетентність укладається вимога, що фахівці за цим профілем підготовки повинні бути носієм економічних та соціальних зрушень, уміти 
трансформувати свої професійні знання відповідно до потреб ринку праці, нових вимог суспільно-економічного середовища, комунікативними вміннями, цінностями демократичного суспільства тощо.

Аналіз актуальних досліджень дозволяє стверджувати, що питання про важливість та доцільність упровадження інноваційних педагогічних технологій у професійну підготовку для забезпечення системи визначених компетенцій сучасного фахівця $є$ аксіоматичним. Проаналізовані тематичні літературні джерела показують, що розвиток педагогічних технологій (зміст, характер, добір інструментальних засобів) у системі педагогічної науки (прикладна педагогіка) пропонується на основі використання варіативних технологій. У комплексних дослідженнях чи окремих публікаціях кожен із науковців для сучасної дидактики пропонує найрізноманітніші версії інноваційної технології. Загалом, вітчизняні науковці розглядають ці процеси переважно виходячи з обґрунтування потреби змін до існуючої структури, стандартів та організаційних форм за певним напрямом підготовки та впровадженням новітніх засобів навчання. Науковцями пропонуються різні версії впровадження інформаційнокомунікаційних технологій з використанням інноваційних методів.

Так, наприклад, стосовно використання системних інноваційних технологій при підготовці спеціалістів за досліджуваним напрямом, К. В. Бурко наводить аргументації, що «для результативного формування фахової компетентності майбутнього спеціаліста з бухгалтерського обліку необхідно постійно вдосконалювати професійну та викладацьку майстерність науково-педагогічного складу та використовувати форми активного навчання» (Бурко, 2018). Досліджуючи стан удосконалення професійної бухгалтерської освіти, М. М. Шигун вказує на переваги, що «надаються сучасними інноваційними технологіями у сфері обліку і аудиту» та обґрунтовує, що інноваційні засоби «необхідні для радикальних змін у набутті навичок та компетенцій бухгалтерів» (Шигун, 2017, с. 335).

Загалом, можна стверджувати, що на думку більшості університетських науковців і зокрема О. А. Дубасюк, «саме завдяки інноваційному імпульсу, який надала «інформаційна хвиля» науковотехнічного прогресу, «прискорився темп цивілізаційного розвитку, а тому подальша логіка розвитку освіти $є$ логікою інноваційних реформ, які відіграватимуть значну роль у модернізації освітніх процесів» (Дубасенюк, 2004 , с. 43). Розглядаючи проблематику формування інноваційного навчального середовища, О. О. Загіка акцентує на тому, що «саме освітні технології, інтерактивні методи навчання, нестандартні форми педагогічної діяльності дозволяють організовувати навчальну роботу в умовах, наближених до реальних, дають очікуваний ефект» (Загіка, 2013, с. 55). Проведений аналіз актуальних досліджень дає змогу зробити висновок, що застосування сучасних педагогічних інноваційних технологій створює 
умови для можливостей вирішення складного педагогічного завдання, у процесах формування професійної компетентності випускника.

Метою статті $€$ дослідження значимості інноваційних педагогічних технологій у процесах формування фахових компетенцій із акцентом на комунікативну компетентність викладачів обліково-економічної сфери, зокрема їх особистісне світобачення. Для реалізації поставленої мети розкрито існуючу проблематику загальнодидактичного і методичного рівня компетентнісного підходу та обґрунтовано значимість інноваційних технологій за цією спеціальністю.

Не до кінця вирішеною проблемою $\epsilon$ теоретичне розв'язання існуючих проблемних питань упровадження інновацій загалом та інноваційні методи навчання в системі формування фахових компетенцій у студентів спеціальності 011 «Освітні, педагогічні науки», які мають базову освіту за напрямом підготовки 07 «Управління та адміністрування». До найбільш проблемних слід віднести, на наш погляд, соціально-педагогічні (розвиток творчого потенціалу учасників навчального процесу) та психолого-педагогічні (готовність викладачів і студентів працювати в інноваційному режимі).

Методи дослідження. У статті використано загальнонаукові методи дослідження: теоретичні - узагальнення і теоретичний аналіз нормативних і науково-педагогічних джерел інформації для обґрунтування вихідних положень дослідження; емпіричні - метод спостереження за навчальним процесом заявленої спеціальності. Методи абстрагування й конкретизації забезпечили формулювання висновків і пропозицій стосовно теоретичних і методичних засад дослідження.

Виклад основного матеріалу. У статті розглядається забезпечення сучасних вимог до загальної компетентності випускника з використанням інновацій (інноваційна педагогічна технологія) на прикладі університетської підготовки спеціалістів у Національному університеті «Львівська політехніка» в межах галузі знань 01 «Освіта», спеціальності 011 «Освітні, педагогічні науки» («магістр 3 освітніх, педагогічних наук» (професійна кваліфікація «викладач обліково-економічних дисциплін»). Матеріали статті стосуються інноваційної педагогічної технології, яка розглянута через призму інтерактивного навчання, інформаційно-ціннісних технологій, технології розвитку критичного мислення.

Розгляд задекларованої проблематики значною мірою стосується навчальних дисциплін освітньо-професійної програми, які є «стиковими», тобто поєднують педагогічні і фахові знання і, відповідно, «цементують» навчальний процес за цим напрямом університетської підготовки. Серед них виділимо такі дисципліни: «Методика викладання обліковоекономічних дисциплін: інноваційні технології»; «Методика викладання обліково-економічних дисциплін: дидактичне проектування»; 
Педагогічні науки: теорія, історія, інноваційні технології, 2020, № 3-4 (97-98)

«Методологія та організація наукових досліджень в обліку й оподаткуванні». Змістове наповнення навчальної програми складається 3 педагогічних та фахово-орієнтованих дисциплін. Важливість упровадження в навчальний процес інноваційних педагогічних технологій полягає в тому, що випускники за цією спеціальністю стають викладачами бухгалтерських і фінансово-економічних предметів у коледжах, технікумах, училищах, а також у загальноосвітніх школах для викладання загальноекономічних предметів (наприклад, предмету «Фінансова грамотність»).

Стосовно задекларованого статтею напряму підготовки зауважимо, що в сучасних публікаціях у сфері бухгалтерської освіти лунають заклики до проведення більш інноваційних і прикладних наукових досліджень, які повинні базуватися на основі застосування соціологічної перспективи та введення результатів цих досліджень у навчальний процес. Науковців різних країн з подібними поглядами нині об'єднує фаховий спеціалізований журнал «Бухгалтерський облік, організація і суспільство», який публікує праці 3 вивчення проблематики ролі і значення бухгалтерського обліку в суспільстві. Автори цієї статті також дотримуються погляду, що бухгалтерський облік $€$ соціально-політичним явищем, а тому для розширення компетентностей студентів доцільним у навчальному процесі $€$ використання, крім суто фахового методологічного інструментарію, методології інших соціальних наук, що забезпечує компетентністний підхід.

Поняття компетентності Законом України «Про вищу освіту» визначено як здатність особи успішно соціалізуватися, навчатися, провадити професійну діяльність, яка виникає на основі динамічної комбінації знань, умінь, навичок, способів мислення, поглядів, цінностей, інших особистих якостей (Закон України «Про вищу освіту», 2019). Проте, на практиці (акредитація, експертні судження про якість освіти, зрештою і суспільний погляд) все ж виникає проблема об'єктивної оцінки професійних компетенцій студента. При узагальненні компетентності необхідно врахувати всі складові цього поняття, їх взаємозалежність та взаємозв'язок. На теперішній час актуальним $€$ вирішення питання вироблення конкретної методики кількісного виразу цього синтезованого понятя, оцінка якого все ще лежить у площині суб'єктивних оцінок і суджень. Реальна практика та аналіз досліджень за цією проблематикою дає змогу зробити висновок, що під цим поняттям розуміють достатньо широке його змістове наповнення. У більшості випадків вважається, що під понятям «компетенція» йдеться про наперед задану вимогу до підготовки особи, ії̈ знань та досвіду діяльності у певній сфері», а зміст понятійного апарату в координатах «компетентність» виявляється в оволодінні компетенцією та включає особисте ставлення до спеціалізації та діяльності (Король, Марущак, 2014, с. 423).

В узагальненому вигляді «компетентність» як синтезоване поняття розкривається через утворення особистості. Це поняття інтегрує в собі знання, 
уміння, навички, досвід та особистісні властивості. У Державному стандарті вищої освіти компетентність визначається як набута у процесі навчання інтегрована здатність особистості, яка складається зі знань, досвіду, цінностей і ставлення, що можуть цілісно реалізовуватися на практиці (Стандарт вищої освіти України). Забезпечення вищою школою ключових компетентностей на загальному фоні концептуальної модернізації вітчизняної освіти пов'язують із інноваційними інструментальними засобами.

Багато науковців стверджують, що «інноваціями в освіті $\epsilon$ впровадження нових методів, форм і підходів до передачі знань, формування вмінь і навичок у студентів (Барабась та ін., 2016, с. 38). Стосовно цілісного (системного) педагогічного процесу, то інновацію найбільш об'єктивно слід розглядати через «введення нового в цілі, зміст, методи й форми навчання та виховання, організацію спільної діяльності викладача і студентів» (Дубасенюк, 2015, с. 5). При цьому обґрунтовується, що інноваційні технології навчання, на відміну від традиційних, $є$ більш ефективними в засвоєнні навчального матеріалу, оскільки «спонукають студентів до творчої роботи та формують особисту позицію щодо сприйняття змісту навчання» (Вітренко, 2010, с. 133).

Педагогічна технологія найчастіше розглядається через системну сукупність і порядок функціонування всіх особистісних та інструментальних засобів, що використовуються для досягнення педагогічної мети, а їх інноваційна складова переважно розглядаються в площині інформаційнокомунікаційних технологій спілкування в різних форматах з використанням різних джерел інформації і супроводжується за допомогою аудіо, відео засобів. Найчастіше застосовується Web-сайт як один із засобів упровадження IKT. У сучасні навчальні процеси широко впроваджено мультимедіа, тобто сукупність прийомів, методів, способів продукування, обробки, зберігання, передавання аудіовізуальної інформації.

Саме поняття «інновація» має складне значення, оскільки містить у собі дві форми: власне ідеї та процеси їх практичної реалізації. При цьому основними елементами освітньої інновації $\epsilon$ їі носій, який має певну інноваційну ідею та проводить інноваційний експеримент; споживач інновації - студент чи група студентів, а також інституції, що забезпечують упровадження інновацій у навчальний процес (заклади вищої освіти; органи управління освітою; науково-методичні установи; наукововиробничі підприємства).

У системі вищої освіти виділяють технологічні, педагогічні, організаційні та економічні групи інновацій. Перші два з цих видів інновацій безпосередньо стосуються формування фахових компетентностей студентів. До технологічних інновацій в педагогікоекономічній освіті слід віднести нові технології навчання, побудову освітніх програм, а також навчально-методичні матеріали. Педагогічні інновації 
включають у себе нові методи викладання і навчання, нові форми та організацію навчальних занять (застосування інтерактивних форм та мультимедійних засобів навчання, використання телекомунікаційних методів конструювання знань, імітаційних технологій, методики відео тренінгу, комп' ютерне моделювання, технологій віртуальної реальності).

Стосовно питань модернізації бухгалтерської освіти в останні роки в Україні проведено чисельні конференції із залученням зарубіжних науковців. На цих наукових заходах розглядаються питання вдосконалення методики викладання бухгалтерського обліку, економічного аналізу і аудиту. Висновками стосовно підвищення якості професійної підготовки фахівців 3 бухгалтерського обліку, активізації навчально-пізнавальної i науководослідної діяльності студентів та розкриття їхнього творчого потенціалу, $\epsilon$ визнання необхідності розробки і впровадження в навчальний процес інноваційних технологій. До таких заходів, насамперед, відносять упровадження комп'ютерно-орієнтованих методичних систем відповідно до змісту фахових дисциплін, в основу яких покладено web технології. У предметній сфері підготовки спеціалістів вважається, «що такі інноваційні технології, як електронне, дистанційне та мобільне навчання відкривають широкі можливості для вирішення завдань із організації самостійної роботи студентів та дозволяють їм отримати доступ до навчальних матеріалів у будьякому місці та в будь-який час, що робить процес навчання більш привабливим та комфортним і стимулює до самоосвіти» (Бурко, 2018).

Важливими у процесах набуття фахових компетенцій визнаються інтерактивні методи навчання, які мають конкретну, передбачувану мету створити комфортні умови навчання, за яких кожен відчуває свою успішність, інтелектуальну спроможність (Варзацька, 2005). Активні методи навчання класифікують за різними підходами, найбільш поширеним із яких $\epsilon$ їх поділ за характером навчально-пізнавальної та ігрової діяльності (Смолкин, 1991, с. 32-38). У межах цієї класифікації вирізняють імітаційні методи (імітація різних аспектів професійної діяльності), які за змістом і характером поділяються на ігрові та неігрові.

Упровадження в навчальний процес методів першої групи забезпечують ігрові процедури і прийоми, ігрові ситуації, дидактична або навчальна гра, ділові ігри. У різних комбінаціях їх використовують під час вивчення предметів «Викладання обліково-економічних дисциплін: інноваційні технології» та предмета з вибіркового блоку «Обліковоаналітичне забезпечення менеджменту». Неігрові методи в навчальному процесі використовують для формування навичок аналізу практичних ситуацій. У теорії добре сформульовані і на практиці апробовані такі методи, як аналіз конфліктів, аналіз проблемних ситуацій, аукціон ідей, імітаційні вправи, диспути, мозкова атака, метод Case Studies, опорні сигнали, методи «Снігова куля», «Коло ідей», «Карусель», аналіз 
конкретних ситуацій та ін. Неімітаційні методи включають стажування на робочому місці, програмоване навчання, проблемну лекцію тощо.

У досліджуваній сфері підготовки спеціалістів ці методи достатньо ефективно використовуються під час вивчення предмету «Викладання обліково-економічних дисциплін: дидактичне проектування». Студенти магістерського рівня спеціальності 011 «Освітні, педагогічні науки», виступаючи в ролі викладача, проводять лекційні заняття для студентів бакалаврського рівня спеціальності 071 «Облік і оподаткування», обравши одну з дисциплін спеціальності. Опрацьоване для таких цілей навчальнометодичне забезпечення з обраної дисципліни, підготовлені матеріали за цією лекцією та набутий досвід поєднання фахових і педагогічних складових стає основою виконання курсової роботи, передбаченої навчальним планом 3 дисципліни «Викладання обліково-економічних дисциплін: дидактичне проектування». Переважно ці напрацювання і стають вибором теми магістерської роботи, у якій окремим розділом визначена фахова педагогічна складова.

Практика показує, що комунікативна підготовка майбутнього викладача обліково-економічних дисциплін опосередковується профілем базової спеціальності 071 «Облік і оподаткування». Виходячи з такої висхідної диспозиції розглянемо фахові компетентності, передбачені Стандартом для другого (магістерського) рівня вищої освіти спеціальності «Облік і оподаткування» і з пропонованими інноваційними методами навчання на спеціальності 011 «Освітні, педагогічні науки» (табл. 1).

\section{Таблиця 1}

\section{Інноваційні методи навчання для забезпечення фахових компетентностей другого (магістерського) рівня вищої освіти спеціальності 071 «Облік і оподаткування»}

\begin{tabular}{|c|c|}
\hline Фахова компетентність & Інтерактивні методи навчання \\
\hline $\begin{array}{l}\text { Здатність } \quad \text { формувати } \\
\text { використовувати обл } \\
\text { прийняття ефективних управлінських рішень } \\
\text { на всіх рівнях управління }\end{array}$ & $\begin{array}{l}\text { Лекції з запланованими помилками, } \\
\text { лекції проблемного характеру } \\
\text { Дидактичні, навчальні, ділові ігри }\end{array}$ \\
\hline $\begin{array}{l}\text { Здатність організовувати обліковий } \\
\text { процес та регламентувати діяльність його } \\
\text { виконавців }\end{array}$ & д і ігри \\
\hline $\begin{array}{l}\text { Здатність застосовувати теоретичні, } \\
\text { методичні і практичні підходи щодо організації } \\
\text { обліку, контролю, планування та оптимізації } \\
\text { податкових розрахунків }\end{array}$ & $\begin{array}{l}\text { Робота в малих групах за методами } \\
\text { «діалог», «синтез думок», метод прес- } \\
\text { формула }\end{array}$ \\
\hline \begin{tabular}{l}
\multicolumn{3}{c}{ Здатність формувати фінансову звітність } \\
за міжнародними стандартами, коректно \\
інтерпретувати, \\
використовувати відповідну інформацію
\end{tabular} & $\begin{array}{l}\text { Лекції проблемного характеру } \\
\text { Дерево рішень, робота в малих } \\
\text { групах за методами «Акваріум», «Ажурна } \\
\text { пилка» }\end{array}$ \\
\hline застосовувати & Інтелектуальні тренінги, ділові ігри \\
\hline
\end{tabular}


Педагогічні науки: теорія, історія, інноваційні технології, 2020, № 3-4 (97-98)

\begin{tabular}{|c|c|}
\hline $\begin{array}{l}\text { методики аналітичного забезпечення сучасних } \\
\text { систем менеджменту }\end{array}$ & \\
\hline \begin{tabular}{l}
\multicolumn{4}{c}{ Використовувати міжнародні стандарти } \\
контролю якості, аудиту, огляду \\
дотриманням вимог професійної етики в \\
процесі практичної діяльності
\end{tabular} & $\begin{array}{l}\text { Лекції проблемного характеру } \\
\text { Кейс метод, дерево рішень, прес- } \\
\text { формула }\end{array}$ \\
\hline $\begin{array}{l}\text { Здатність } \\
\text { удормулювати завдання, } \\
\text { удоналювати методики та впроваджувати } \\
\text { сучасні методи обліку, аналізу, аудиту й } \\
\text { оподаткування }\end{array}$ & $\begin{array}{l}\text { Багатоцільові, проблемні лекції, } \\
\text { лекції-брейнстормінг, лекції із заздалегідь } \\
\text { запланованими помилками }\end{array}$ \\
\hline $\begin{array}{l}\text { Здатність виконувати адміністративно- } \\
\text { управлінські функції у сфері діяльності суб'єктів } \\
\text { господарювання }\end{array}$ & $\begin{array}{c}\text { Лекції } \quad \text { прес-конференції, } \\
\text { брифінги, лекції «круглий стіл» }\end{array}$ \\
\hline $\begin{array}{l}\text { Здатність здійснювати діяльність } 3 \\
\text { консультування у сфері обліку, аналізу, } \\
\text { контролю, аудиту, оподаткування }\end{array}$ & $\begin{array}{l}\text { Лекції-прес-конференції, } \\
\text { екскурсії, лекції з застосуванням зворотного } \\
\text { зв'язку, мозковий штурм, діагностика } \\
\text { проблеми }\end{array}$ \\
\hline $\begin{array}{l}\text { Здатність проводити наукові } \\
\text { дослідження з метою вирішення актуальних } \\
\text { завдань теорії, методики, організації та } \\
\text { практики обліку, аудиту, аналізу, контролю та } \\
\text { оподаткування }\end{array}$ & $\begin{array}{l}\text { Робота з електронними посібниками } \\
\text { наукометричними базами даних }\end{array}$ \\
\hline
\end{tabular}

3 відомих новітніх методів у навчальний процес для набуття деякої групи визначених компетентностей під час вивчення обліково-економічних дисциплін поступового впровадження набувають відмінні від традиційних і популяризовані для навчального процесу лекції: багатоцільові, проблемні лекції, лекції-брейнстормінги, лекції із заздалегідь запланованими помилками. У ситуації, що склалася, особливого значення набувають форми дистанційного навчання, використовують лекції-конференції, лекції пресконференції, лекції-брифінги, лекції «круглий стіл». Очевидною $\epsilon$ ефективність такого виду навчальних занять, як лекції-бесіди, лекціївізуалізації, лекції-екскурсії, лекції із застосуванням техніки зворотного зв'язку (інтерактивні), бінарні лекції. Вони вважаються такими, що забезпечують більш ефективний підхід до передачі та сприйняття навчального матеріалу. На основі вже апробованих форм виділимо лекції проблемного характеру, на яких студенти знаходяться в постійному процесі «співмислення» з лектором, i зрештою стають співавторами у вирішенні проблемних завдань. Практика їх упровадження показує, що лекції такого типу сприяють активному засвоєнню, глибшому запам'ятовуванню, розвитку творчого мислення (перенесення в інші ситуації), підвищення інтересу до змістового викладання обліково-економічних дисциплін.

Для набуття навичок студентами цієї спеціальності здатності формувати адекватну обліково-економічну інформацію для прийняття ефективних управлінських рішень доцільно проводити тематичні ділові ігри. Так, 
наприклад, із дисциплін «Облік і аналіз в корпораціях» та «Обліковоаналітичне забезпечення менеджменту», що вивчаються за вибором студентів, упроваджуються заняття ігрового характеру на такі теми: «Складання корпоративної фінансової звітності», «Я - фінансовий директор корпорації», «Інформаційна база управління корпорацією», «Об'єднання капіталу на підприємствах корпоративного типу». Такі ігри мають формуються в такий спосіб, щоб забезпечити послідовне дотримання облікової діяльності на підприємствах корпоративного типу. У розвиток наведеного навчального методу під час вивчення обліково-економічних дисциплін практикується робота в малих групах за відомими методами «Діалог», «Синтез думок», «Спільний проект», «Акваріум», «Ажурна пилка», «Прес».

Однією $з$ форм організації занять із викладання обліковоекономічних дисциплін $\epsilon$ case-study (ситуаційний аналіз) - вивчення й обговорення конкретних обліково-економічних ситуацій. Використання цього методу дозволяє навчити розуміти за теоретичними моделями реальні обліково-аналітичні процеси, аналізувати проблеми, що виникають у фаховій сфері, аргументувати власні висновки на основі теоретичного матеріалу. Педагогічна цінність цього методу полягає в тому, що у процесі навчання разом із професійними інтенсивно розвиваються й особистісні здібності, формуються практичні навички та вміння в межах визначених освітньою програмою фахових компетенцій: аналітичні (уміння класифікувати інформацію, виділяти суттєву та несуттєву, аналізувати та представляти ії), творчі (знаходити варіанти рішень та вибирати оптимальні для відповідної ситуації), комунікативні (уміння вести дискусію, переконувати оточуючих, захищати власну точку зору, переконувати опонентів, складати короткий, переконливий звіт), соціальні (оцінювати поведінку інших, удосконалювати вміння слухати, підтримувати в дискусії чи аргументувати протилежну думку).

Набуття професійних компетентностей за досліджуваним напрямом підготовки забезпечується під час проведення практичних занять 3 дисциплін, що вивчаються за напрямом 07 «Управління та адміністрування». При цьому практикується використання методу PRESformula - який базується на технології аргументованого судження, що спрямована на рефлексію студентів (розвиток здібностей ставити питання, виробляти різноманітні аргументи, приймати незалежні продумані рішення; удосконалення вмінь студентів працювати 3 інформацією, створюючи власну систему сприйняття; формування вміння переконувати та обґрунтовувати власну думку; засвоєння дисципліни на різних рівнях).

Однією з інноваційних педагогічних технологій $€$ методика PRESformula, яка може застосовуватися для закріплення вивченого матеріалу, зокрема перевірки засвоєння матеріалу, винесеного для самостійної роботи студентів. Технологічність прийому полягає в тому, що студенти для 
підсумкового контролю на практичних заняттях готують короткий виступ, що складається з кількох взаємопов'язаних елементів. В узагальненому вигляді вони структуровані таким чином: Position - позиція (у чому полягає ваша точка зору), Reason - пояснення (на чому базуються ваші судження, аргумент на підтримку вашої позиції), Example - приклад (факти, що ілюструють ваш аргумент), Summary - резюме (висновок, що треба зробити, заклик до певних дій). Підготовлене має за мету сформувати логіку студента стосовно обґрунтування своєї позиції), уміння доводити правоту своєї позиції з використання фактів, що мають місце на практиці) і сформулювати власний висновок. У такому виступі, що складається 3 декількох речень, студент чітко заявляє свою позицію, приводить тільки один аргумент, але він коректно сформульований і проілюстрований, та підтверджує правильність свого судження. При цьому студент не маєте можливості вимовляти порожніх фраз і обтічних виразів. Виступ із використанням PRES-formula займає одну-дві хвилини. її зручно використовувати не тільки в ситуації, коли час, відпущений на дискусію, обмежений, а й коли завдання педагога - навчити студента відповідати посуті, не використовуючи розмитих фраз і неясних суджень (Вагіс, 2017).

Узагальнено можна стверджувати, що головними перевагами інноваційних педагогічних технологій $€$ створення атмосфери співпраці за схемою: викладач-студент, студент-студент, студент-комп'ютер, студентвикладач. Під час практичного використання методики інтерактивного навчання для вивчення дисциплін професійного спрямування важливим $є$ дидактичне забезпечення самостійної роботи студентів із визначенням параметрів: результатів вивчення навчальної дисципліни (опис професійної компетенції студента з вивчення курсу); термінів виконання завдання, інтерактивних контактів із викладачем.

Висновки та перспективи подальших наукових розвідок. Матеріали дослідження вказують на різноманітність підходів як до самого змісту сучасних інноваційних педагогічних технологій, так і способів, форм їх упровадження в навчальний процес. Під час вибору педагогічної технології слід, насамперед, ураховувати напрям професійного навчання, зокрема специфічні особливості напряму підготовки, ключові компетентності професійної кваліфікації, а також потенціал професійно-педагогічної та методичної майстерності викладацького складу і здатності студентів до оволодіння знаннями. 3 точки зору ефективного використання інноваційної складової в системній технології важливими факторами виступають наявність і ступінь дидактичних і технічних засобів навчання.

Необхідність та ефективність упровадження в систему університетського навчання інноваційної системи педагогічних технологій підтверджується їх позитивним впливом на формування компетентностей у процесі підготовки викладачів обліково-економічних дисциплін. Такі 
спеціалісти готуються для закладів передвищої освіти, які водночас $\epsilon$ потенційно університетськими викладачами. Інноваційні технології в навчальному процесі мають великий освітній і розвивальний потенціал, забезпечують максимальну активність студентів у навчальному процесі, оптимальний час навчання, його результативність та набуття визначених компетентностей.

Інноваційні методи навчання об'єктивно сприяють підвищенню рівня засвоєння знань, вони розширюють пізнавальні можливостей студентів, забезпечують їх активну участь у процесі навчання, підвищуючи мотивацію, спрощують та пришвидшують процес контролю знань, забезпечують партнерство між викладачем та студентами. Упровадження таких методів у навчальний процес забезпечує набуття комунікативних умінь та здатності організовувати обліковий процес і роботу його виконавців, знайти адекватні теоретичні, методологічні та практичні підходи для контролю, планування й оптимізації обліково-аналітичної роботи, уміння швидко, оперативно та правильно орієнтуватися в змінах обліково-податкового законодавства.

Стосовно апробації в досліджуваній сфері підготовки спеціалістів, то можна зробити висновок про те, що застосовані в комплексі 3 традиційними інноваційні технології сприяють формуванню фахових компетентностей майбутніх викладачів-обліковців. Перспективи подальших досліджень спрямовані на використання інтерактивних методів навчання та дистанційної форми навчання у професійній підготовці викладачів досліджуваного профілю.

\section{ЛІТЕРАТУРА}

Барабась, Д., Джафаров, Д., Шпак, І. (2016). Освітні інновації та їх імплементація в Україні. Науковий вісник Одеського національного економічного університету, 3, 35-54 (Barabas, D., Dzhafarov, D., Shpak, I. (2016). Educational innovations and their implementation in Ukraine. Scientific Bulletin of Odessa National Economic University, 3, 35-54).

Бурко, К. В. (2018). Інноваційні технології навчання у підготовці фахівців з бухгалтерського обліку. Електронне наукове фрахове видання «Ефрективна економіка», 5. Режим доступу: http://www.economy.nayka.com.ua/pdf/5 2018/161.pdf (Burko, K. V. (2018). Innovative learning technologies in training specialists in record-keeping. Electronic scientific professional publication "Effective Economics", 5. Retrieved from: http://www.economy.nayka.com.ua/pdf/5 2018/161.pdf).

Baric, А. (2017). Формування фахової компетентності студента як синергетичний процес. Ukrainian Journal of Educational Studies and Information Technology, 5 (2), 5-8 (Vahis, A. (2017). Formation of professional competence of the student as a synergetic process. Ukrainian Journal of Educational Studies and Information Technology, 5 (2), 5-8).

Варзацька, Л. (2005). Інтерактивні методи навчання: лінгводидактичні засади. Дивослово, 2, 5-9 (Varzatska, L. (2005). Interactive teaching methods: linguodidactic principles. Dyvoslovo, 2, 5-9).

Вітренко, О. В. (2010). Досвід використання методики інтерактивного навчання під час 
викладання професійних дисциплін зі спеціальності облік і аудит. Вісник Донецького університету економіки та права, 2, 128-133 (Vitrenko, O. V. (2010). Experience in using the methodology of interactive learning in teaching professional disciplines in the specialty accounting and audit. Bulletin of Donetsk University of Economics and Law, 2, 128-133).

Гулько, О. В. (2012). Проектна освіта як один з напрямків освітніх трансформацій: філософсько-історичний аспект. "Гілея: науковий вісник». Збірник наукових праць, 56, 471-477 (Hulko, 0. V. (2012). The project education as one of the ways of educational transpormation: philosophic-historical acpect. Collection of scientific papers «Hileia: scientific herald», 56, 471-477).

Дубасенюк, О. А. (2004). Інноваційні навчальні технології - основа модернізації університетської освіти. Освітні інноваційні технології у процесі викладання навчальних дисциплін: Збірник наук.-метод. праць. Житомир: Вид-во ЖДУ, сс. 14-47 (Dubaseniuk, 0. A. (2004). Innovative teaching technologies - basis for modernization of university education. Educational innovative technologies in the process of teaching. Collection of scient.-meth. works. Zhytomyr: Publication Zhytomyr's University, pp. 14-47).

Дубасенюк, О. А. (2015). Профресійно-педагогічна освіта: методологія, теорія, практика. Т. 1. Житомир: Вид-во ЖдУ імені Івана Франка (Dubaseniuk, О. А. (2015). Professional and pedagogical education: methodology, theory, practice. Vol. 1. Zhytomyr: Zhytomyr Ivan Franko State University).

Загіка, О. О. (2013). Інноваційне навчальне середовище - запорука професійної компетентності та конкурентоспроможності випускника ПТНЗ. Профресійна освіта: проблеми і перспективи, 5, 55-59 (Zagika, O. О. (2013). Innovative learning environment as a formula of professional competence and competitiveness of a vocational school graduate. Vocational education: problems and prospects, 5, 55-59).

Закон України «Про вищу освіту» (Law of Ukraine "On higher education") (2019). Retrieved from: https://zakon.rada.gov.ua/laws/show/1556-18.

Король, В. П., Марущак, О. В. (2014). Термінологічні аспекти формування професійної компетентності майбутнього фахівця. Сучасні інформаційні технології та інноваційні методики навчання у підготовці фрахівців: методологія, теорія, досвід, проблеми, 37, 421-427 (Korol, V. P., Marushchak, O. V. (2014). Terminological aspects of the formation of professional competence of the future specialist. Modern information technologies and innovative teaching methods in specialists' training: methodology, theory, experience, problems, 37, 421-427).

Смолкин, А. М. (1991). Методы активного обучения. М.: Высшая школа (Smolkin, А. М. (1991). M ethods of active learning. M .: Higher School).

Стандарт вищої освіти України: другий (магістерський) рівень, галузь знань 07 Управління та адміністрування, спеціальності 071 - Облік і оподаткування (Higher education standard of Ukraine: second (master's) level, field of knowledge 07 - M anagement and administration, specialty 071 - Accounting and taxation).

Шигун, М. М. (2017). Професійна бухгалтерська освіта і кваліфікація: європейські орієнтири. Облік, оподаткування і контроль: теорія та методологія: зб. матеріалів міжнар. наук.-практ. інтернет-конф. Тернопіль: ТНЕУ, сс. 335-337 (Shyhun, M. M. (2017). Professional accounting education and qualifications: European guidelines. Accounting, taxation and control: theory and methodology: proceedings of international. scientific-practical internet conference. Ternopil: TNEU, pp. 335-337).

Asonitou Sofia. The necessity to develop university Teachers Pedagogical Training. A new 
Institutional Theory Approach (Department of Business Admimastration Technological Educational Institute of Athems). Retrieved from: https://www.researcggate.net/publication/319465046.

International Federation of Accountants (IFAC). Retrieved from: http://www.ifac.org/. Paisey, C., Paisey, N. J. (2004). An analysis of accounting education research in Accounting Education an international journal. Accounting Education, 13 (1), 69-99.

\section{PEЗЮME}

Лемишовская Олеся, Яремко Ирина. Обеспечение профессиональной компетентности в процессе подготовки преподавателей учетно-экономических дисциплин с использованием инновационных педагогических технологий.

Статья посвящена теоретическому обоснованию значимости и содержания инновационных педагогических технологий для обеспечения профрессиональной компетентности будущего преподавателя профессионального обучения. Приведены современные тенденции в развитии университетского образования и проанализировано содержание и характер предлагаемых педагогических технологий с использованием инновационного инструментария. Раскрыто состояние и проблемы использования инновационных педагогических технологий в обеспечении специфических компетентностей преподавателя учетно-экономических дисциплин. На основе обобщения тематических исследований и практики срормулированы отдельные предложения использования инновационного инструментария по исследуемому профилю подготовки специалистов.

Ключевые слова: преподаватель учетно-экономических дисциплин, профессиональная подготовка образовательные инновации, инновационная образовательная деятельность, компетентности, технологии в образовании, педагогические технологии.

\section{SUM MARY}

Lemishovska Olesia, Yaremko Iryna. Ensuring professional competence in the process of training teachers of accounting and economic disciplines using innovative pedagogical technologies.

The article is devoted to the theoretical substantiation of the significance and content of innovative pedagogical technologies to ensure the professional competence of the future teacher of vocational training. The modern tendencies in the development of university education are given and the content and character of the offered pedagogical technologies with the use of innovative tools are analyzed. The article considers modern requirements for the general competence of the graduate with the use of innovations (innovative pedagogical technologies) on the example of university training within the field of knowledge 01 «Education», specialty 011 "Educational, pedagogical sciences" ("Master of Educational and Pedagogical Sciences", professional qualification "Teacher of accounting and economic disciplines").

The state and problems of using innovative pedagogical technologies in providing specific competences of a teacher of accounting and economic disciplines are revealed. The most problematic are socio-pedagogical (development of creative potential of participants in the educational process) and psychological and pedagogical (readiness of teachers and students to work in an innovative mode).

Innovative pedagogical technologies are considered in the article through the prism of interactive learning, information and value technologies, technologies of development of critical thinking, a set of methods, techniques, tools and forms of organization of the educational process in the parameter of psychological and pedagogical, scientific and technological and socio-economic innovations. Consideration of the declared issues largely concerns the disciplines of the educational-professional program, which combine 
pedagogical and professional knowledge and, in fact, "cement" the educational process in this area of university training. The practical experience of approbation of teaching skill by students was acquired during lectures and practical classes in the disciplines studied in the direction 07 "Management and administration". On the basis of generalization of thematic studies the guidelines for the development of innovative pedagogical technologies and use of innovative tools on a researched profile of training are formulated.

Key words teacher of accounting and economic disciplines, vocational training, educational innovations, innovative educational activity, competence, technologies in education, educational technology.

\section{Удк 378.016:577.1]:001.895}

Юлія Ліцман

Сумський державний університет ORCID ID 0000-0001-5748-2213

Ольга Швець

Сумський національний аграрний університет ORCID ID 0000-0001-9872-3829

Наталія Осьмук

Сумський державний педагогічний

університет імені А. С. Макаренка ORCID ID 0000-0002-0784-1350

DOI 10.24139/2312-5993/2020.03-04/091-107

\section{ОРГАНІЗАЦІЯ ЗМІШАНОГО НАВЧАННЯ ЗА ДОПОМОГОЮ «GOOGLE CLASSROOM» ПIД ЧАС ВИВЧЕННЯ БІООРГАНІЧНОÏ XIMIÏ ЗДОБУВАЧАМИ МЕДИЧНИХ СПЕЦІАЛЬНОСТЕЙ}

Стаття присвячена проблемі підвищення ефективності хімічної підготовки студентів спеціальності «Медицина». Обгрунтовано актуальність залучення електронного, мультимедійного та мобільного контенту в навчальний процес. Підтверджено, що умовою ефективності реалізації змішаного навчання є поєднання аудиторної та позааудиторної роботи. Здійснено експериментальну перевірку результативності застосування розробленої методики вивчення біоорганічної хімії в умовах змішаного навчання на платформі «Google Classroom». Установлено позитивний влив запропонованої методики на рівні навчальних досягнень студентів з хімії.

Ключові слова: змішане навчання, експеримент, «Google Classroom», заклад вищої освіти, здобувачі медичних спеціальностей, викладання хімії, методика викладання біоорганічної хімії.

Постановка проблеми. Цифровий контент набуває все більшого поширення в житті сучасного суспільства. Змінюється спосіб комунікації між людьми, що призводить до розвитку нового типу мислення. У таких умовах роботодавцями висуваються нові вимоги до майбутніх фахівців. Серед яких: критичне мислення, уміння комплексно вирішувати проблеми, медіаграмотність і знання основ ІТ-технологій, креативність, готовність до неперервної освіти, до розвитку емоційного інтелекту. Формування таких компетентностей потребує зміни способу навчання студентів. Світова 